\title{
THE EMERGENCE OF PAKISTAN AND TURKISH PUBLIC OPINION IN 1947
}

\author{
Prof.Dr. Ilber ORTAYLI
}

The year 1947, was a turning point of the world history when the old order began to collapse and old Europe was divided into two idcological spheres. In this year a young state of an old pcoplc and the land of an ancient culture was emerging. In June 1947 Indian subcontinent has been divided into two countries. Muslim people of subcontinent formed their own state, Pakistan. For Muslims of Indian subcontinent Kemalist Turkey and Turks, their war of Resistance (1919-1922) was an encouraging guide to build their futurc. Certainly the support of Indian Muslims during the days of Resistance war constitutes a ramarquable aspect of Turkey's history. In the darkest day of the Turks, (1938 10th of November the day of decession of Atatürk) Kaid-i azam M.A. Jinnah held a spech before the members Muslim League, expressing deep mourning of the Muslims, because of the loss of the most brilliant general and statesman of the East, he asked to his audience; "as we have such a leader and admiring figure, should we still suffer of this dark era?!" The answer raised in one word; "no more".1

In 1947, Turkish political system was enjoying the second year of multiparty system. The economic suraits and the memories of war years and martial law of one-party system provoked a large wave of opposition criticism. Internal politics turned day by day into a warmer conflict. In a few months several parties, from radical left to rightwing had been established. One of the most interesting developments was the comprimising attitude of the government with the oppositional forces, in matters of radical secularism. But in spite of this, the country turned into a stage of polemics between the liberal opposition and Republican Party. Internal political life created an anxious spherc. Or the other hand, the international ideological conflict and political crisis also had its impacts on Turkey. The cold war between East and West, focused in this country for a while, because of the demands of Soviet Union on the Turkish Straits. The general conditions of the Balkans and Sovict demands forced Turkey to arrange an alliance in order to resist the threats of the Eastern block; cven Greek politicians in those days, like Chaldaris had given intervicws about a confederational system between Greece and Turkey. ${ }^{2}$ Besides these problems, which troubled the burcaucracy and public circles as well, we can not put aside the unfavorable conditions of an underdeveloped communication and

\footnotetext{
1 Pakistan Postast, - Turkish Bulletin of the Embassy of Pakistan in Ankara - Nov. 1989, p.1.

2 Cumhuriyet (30 May 1947), p. 11 .
} 
information-network which existed between Turkcy and Indian subcontitenant, before the Independence. Turkish neswpapers had no forcign correspondents, not at all in India and could not utilize broadcasting. The news on India had to be picked up either from WestEuropean mass media, or rarely from some eyewitness reporters who passed through Turkey. Turkey has today in neighhbouring countries, permanent correspondents and some press contacts in Pakistan. The political life in Pakistan is fallowed better, and political events are reflected sooner. It can be considered as a revolution, that a Turkish TV man today can conduct interviews with ordinary people on the strects of Pakistany towns.

Inspite of these above-mentioned negative circumstances 45 years ago, it was an amazing fact, that the turkish newspapers in those days could give interesting information and leading pens of the Turkish press made encouraging commentaries on the Muslim movement in the Indian subcontinerit day by day in 1947. This dcep interest and suppor had its roots in the common historical background of the two pcoples.

After the Second World-war there was an obvious revival in the Islamic world. On 12th April 1947 Sheikh Senusi expressed his wish for a union with Turkey; so he obviously wanted to restore the old union, which had been ruined after the Italian annexation of Tripolis (Trabulusgharb) in 1912.3 ${ }^{3}$ Later he asked for experts and even administrators from Turkey. The sympathy of Turkish public opinion upon the Muslims of India based not only the same faith, Islam, since even the secular Turkish literary and political figures were in support of them. Almost every day' between July-December 1947, news arrived from Muslim provinces could be read in newspapers, such as trains carrying Muslim refeguees under miscrable conditions, or the attacks of Indis and Sighs upon Muslim migrant groups. For example, on 27th of August 1947, in the station of Tokhora the Sighs attacked a Muslim train and massacred some hundreds of Muslim migrants. The same day the message of Prime Minister Liyagat Ali Han has been read by the Turks in newspapers, where he expressed the gratitude of Pakistan to the Turkish leaders, because of the support of Indian Muslims by the government and the people as well. ${ }^{4}$ In those days Turkish newspapers and leading pens took their part in polemics between Muslims and India, on behalf of the future Pakistan. Against the propaganda of Indian leaders, that this country (Pakistan) could only be created artificially and would have no features, leading scholar Omer Rlza Dogrul ${ }^{5}$ writes his opinion in Cumhuriyct, as follows; "Many Indians however can not bear and stand to hear the conccpt of Pakistan and claim, that putting Muslim parts of India under this name is an insult. But the reality is on the contrary, as the Muslim leader Jinnah mentions, Pakistan is a combination of Panjab, Kashmir, Sind and Belujistan. Pakistan is stressed for a while in Turkey as a country of "pak people-clean and purc"... Omer Rlza Doğrul argues against the Indian thesis; "the Islamic background of Pakistan is closely connected to the history of Turks. Islam found its stronghold as early as in the first centuries of Hijra and Turkish conquerers and commanders entered and settled there. They established there like Babur, the grandson of Temurlane, an empire and later Akbar Shah, who expanded its boundaries and covered almost all India. The Fall of this empire happened only 90 years ago, not even a century. It is a happy event, that Muslims in India now proclaimed, under their

\footnotetext{
3 Cumhuriyet (12th April 1947), p. 1.

4 Cumhuriyel (27 August 1947) p. 1-4.

5 Cumhuriyet (7 June 1947) p. 3.
} 
able leaders, an independent state. We are glad, that India also took its independence. We wish that they live in peacefull coexistence and build their future together brotherly and work for their welfare". A radical secularist leader and leading pen of Turkish press Necmeddin Sadak, clearly proposed his positive opinion about the formation of Muslim Pakistan, in September 4th issue of $A k_{s} a m^{6}$ and uscd rather a calm style of a sociologist: "There is not a unified and single India. For India we better use the french tem in plural form, "les Indes". India still suffers of many ethnic problems, here muslim Pakistan unlike India owes his existence to a religious and cultural unity. Unlike India, Pakistan will not suffer of certain problems of strange caste system. Islam in these regions had solved, in the course of history the institutions and problems of caste system. So the Muslim socicty of Pakistan has more chance than India to realize the modernization and unification of the country and people." He adds: "Because of that structure, the emergence of Muslim Pakistan would help the existence of peace in Indian subcontinent..."

Certainly the most erudite pen of the time, especially in this subject was the brillant novclist and politician Mrs. Halide Edip Adivar, in those days professor of English litcrature at the University of Istanbul. In one of her articles she justifies the necessary and undeniable formation of the state of Pakistan as follows: "Formerly I had my doubts about the formation of Pakistan. But later I wrote a book on this question Inside India-. Pakistan has another cultural and historical background, and they had to be liberated from Hindu dominance in industry and commerce. Besides, the social structure of this country is based on the principles of Islam, that means social equality, which is far away from caste system". ${ }^{7}$ In 1947 the she tried to enlighten the Turkish public in this matter, as she did ten years ago with her erudite style and arguments in England. There she published a book, with the title "Inside India" in 1937, which still keeps its value as a first hand reference text on this subject. She explains the role of Islam in the formation of Muslim India as following: "With regard to the clash between the Hindu and Muslim systems, the principal difference between them was that while Islamic system gave latitude for social cvolution, Hinduism gave latitude to the mind only and insisted on a fixed social pattern."-She evaluates the social patterns of Pakistan positively for a modemization.

In 12th of December 1947, Malik Firuz IIan Noon, special envoye of Quadiazam Muhammed Ali Jinnah (Gencral governor of Pakistan) held a visit to Turkey and in the press confcrence he gave an intervicw: 9 " Pakistan admires the glorious past of Turkey, and its administrative achievements and organizatorial abilities in the past and present times. Pakistan is now two months old, in a near future two brother countries are going to establish close cultural, commercial and political relations... A new happy era will cmerge for these two countries...."

6 Necmeddin Sadak, "Hindistan ile Pakistan-India and Pakistan", in Akşam (4th of September, 1947) p. 1.

7 H.Edip Adıvar, "Hindistanın Içindeki Kavga- The Conflict in India"in Akşam (20 Nov. and 27 Nov. 1947) p. 5-6.

8 Halide Edip, Inside India London, George Allen and Unwin- 1937, p. 314. For the further discussions on Halide Edip's ireas in Indian press see the paper of Bülent Yorulmaz "Hind basınında Halide Edip Adıvar"in Türklük Arastırmaları Dergisi, 1984, No. 4 p. 179-182.

${ }^{9}$ Cumhuriyet (12 Dec. 1947) p. 1. 